\title{
Quality Management Practices and Performance of ISO 9000 Certified Middle Level Colleges in Kenya
}

\author{
Jack O. Kelly ${ }^{1}$ \\ Kenya Medical Medical Training College \\ Vincent N. Machuki ${ }^{2}$ \\ School of Business \\ University of Nairobi
}

\begin{abstract}
Quality management practices influence the way organizations perform. Most studies argue that firms which embrace QMP outperform those that do not. Some studies however show no impact of embracing QMPs. There is no consensus as to how QMPs affect firm performance. The objective of the study was to determine the influence of quality management practices on performance of ISO 9000 Certified middle level colleges in Kenya. Through a descriptive cross-sectional survey, data were gathered using a semi-structured questionnaire from 50 Middle Level Colleges between January and August 2015. Both descriptive and inferential statistical analyzes were undertaken on the data. Findings of the study indicate that QMPs have an effect on overall performance of middle level colleges. Specifically, findings show QMPs to have significant effects on Non-financial but not on financial performance. The study concluded that QMPs enable organizations to realize superior performance. From the study findings, implications for policy, practice and methodology have been pointed out. Based on the study's limitations, suggestions for further research have been suggested
\end{abstract}

Keywords: Quality, Management Practices, Performance

\section{Introduction}

Strategic managers, scholars and practitioners have for a long time attempted to explain why firms operating within an industry register varying performance. Strategies that an organization formulates and adopt in the short and long run may affect the performance of firms. To effectively distinct itself from competition and achieve competitiveness, an organization may choose to adopt quality management practices (Muchara, 2012). There has been optimism and skepticism in equal measures on the effect of QMS on organizational performance.

Performance is a recurrent theme to scholars and practitioners in strategic management field. Pajoro and Sohal (2006) posit that quality management practices have a positive impact on a firm's performance. Schniederjans and Schniederjans (2015) link QMPs with innovation and hence performance. The contribution of QMPs on firm performance is further propelled by Herzallah, et al. 2014 who argue that an organization adopting quality management practices may attain higher performance through either differentiation strategy or cost leadership. Dean and Bowen (1994) however argue that from a strategic management perspective, QMP is concerned more with strategy implementation, or deployment, rather than strategic choice, or intent and hence has little contribution to performance of organizations. There still exists no concensus as to how QMPs contribute to firm performance.

Performance of middle level colleges is of great concern because they supply much needed work force to the Kenyan economy. Middle level colleges fall within the education sector which is relied upon to provide much needed human resources necessary for the achievement of vision 2030. The study is interested in middle level colleges because their performance directly impacts on the achievement of vision 2030. The performance of these organizations depends on the strategies they put in place. To enhance performance, middle level colleges have embraced quality management practices through ISO 9000 Certification. How quality management practices affect the performance of these organizations remains to be determined. This study is motivated by the need to establish the effects of quality management practices on organizational performance. The study aims to generate information which will assist managers make strategic decisions on certification and performance. 


\section{Theoretical Foundation}

The concept of firms embracing QMPs can be explained theoretically through the neo institutional theory. The neo- institutional theory explains that organizations operate in an environment dominated by rules, taken for granted assumptions, myths, and routines about what constitutes appropriate or acceptable organizational forms and behaviour (DiMaggio \& Powell, 1991). Kinuu (2014) explains the theory as aligning firm's strategy with internal factors of the organization and seeking to examine the preferences, behaviors and actions of organizations. In general, this perspective assumes that the institutional environment constrains the organization and determines its internal structure and, consequently, the behaviour of the actors in the organization. The theory is applicable in explaining why organizations embrace practices like ISO 9000 certification.

A firm's performance is anchored in the stakeholders' theory. The stakeholder theory of balanced score card as explained by Kaplan and Norton (1992) suggests that organizational performance has four aspects namely financial, customers' perspective, learning and growth and internal business processes. The sustainable balanced score card (SBSC) has an additional perspective of non-market performance. Ogendo (2014) argues that sustainable balanced score card is a strong predictor of an organization's performance based on the stated perspectives.

Stakeholder theory assesses an organization's performance against the expectation of various stakeholder groups that have a particular interest in the effects of an organization's activities (Hubbard, 2009). The choice of adopting the sustainable balanced score card to measure a firm's performance emanates from the fact that it allows various aspects of performance to be gauged and hence a holistic view of the health, wealth and welfare of the firm (Kinuu, 2014). The SBSC enables firms to be more strategic about their organizations (Caraiani et al, 2012). It allows organizations to adopt a long term view about the strategies they adopt and their impact on the survival and excellence of the firm.

\section{Quality Management Practices}

The American Society for Quality Control (ASQ) defines quality as totality of features and characteristics of a product or services that bear on its ability to satisfy given needs (ASC, 2008). Quality hence is the degree of conformance of a product, process or service to the requirements of the customer or the ability of a product, a process or a service to consistently meet or exceed customer expectations. Quality Management (QM) is defined as a philosophy or an approach to management made up of a set of mutually reinforcing principles each supported by a set of practices or techniques (Dean \& Bowen, 1994). Quality management has been studied as a practice. Sousa and Voss (2002) point that through quality management practices, managers work to achieve organizational improvements in terms of specific dimensions and strategic concern. Evans et al (2002) define practices as activities that occur within the organization's infrastructure so as to achieve organization's goals.

Quality management practices have been broken down into indicators which include Leadership, Information and analysis, Strategic planning, Human resource development, process management for quality, Supplier relationship, Customer orientation and Quality results (Rao et al. 1997). Quality management practice variables have been treated as independent, moderating or mediating. Saraph et. al (1991) study of QMP, context and firm performance in both service and manufacturing firms in US found that managers' perception about ideal and actual quality context affect performance.

Douglas and Judge (2001) study of TQM and competitive advantage focusing on highly regulated US health sector found positive correlation between ISO 9000 certification and organizational performance. Powell (1995) study found that tacit TQM contextual features like top management commitment, culture and employee empowerment positively influenced performance. Bou and Beltran (2006) studied the effects of adopting QMP on SMEs in Spanish service firm and their impact on performance found soft QM features to affect performance. In Kenya, Okwiri (2010) conducted a study on the relationship between ISO certification and operational performance of Government agencies. Few or no study seems to have addressed the effect of QMPs in Kenyan middle level colleges.

\section{Organizational Performance}

Organizational performance is a measure of the value created by an organization, or the financial or non-financial outcomes that result from management decisions and the execution of those decisions by members of the organization (Grant, 1996). 
The independent variables are proposed as determinants of the changes in the dependent variables. The changes in the dependent measures are considered to represent performance caused by the variations in the independent measures.

The general concept of performance is anchored upon the idea that an organization is an association of productive assets, including human, physical, and capital resources, for the purpose of achieving a shared purpose (Barney, 2001). The essence of organization performance is to create value. Performance is a multi-dimensional concept allowing value to be created in varying ways (Cameron, 1986). How the value created is being measured is the concern of performance.

Pearson and Robinson (2005) state that balanced scorecard is a set of measures directly linked to an organization's strategy. Hubbard (2009) argue that a holistic diagnosis of firm's performance need not only concentrate on financial performance but also focus on environmental, social, learning and growth and internal business processes. Strategies adopted by the organization should ensure both short term and long term performance targets. Realization of strategies can be enhanced by adopting quality management practices (Pajoro and Sohal, 2006).

\section{Quality Management Practices and Organizational Performance}

An organization adopting quality management practices may attain higher performance through either differentiation strategy or cost leadership. Porter (1980) suggests that a differentiation strategy aims to create a product that customers see as unique. A firm adopting this strategy selects one or more attributes or characteristics that customers perceive as important, and uniquely positions itself to excel in those attributes leading to a premium price. Philips et al. (1983) hold that among the many sources of differentiation, quality is the approach that most often characterizes a differentiation strategy. This is because quality creates a competitive advantage through customer loyalty as well as minimizing customer sensitivity to price. Phillip et al (1983) support the argument that product quality exerts beneficial effect on cost position via market share. They conclude that quality is inversely associated with cost. Quality of a product could also impact directly on cost at production level by minimizing rework.

Findings showing effects of QMP on performance have been inconclusive. Researches showing positive relationship between QM practices and performance include, Ho et al., (2001), Kaynak (2003), Shah and Ward (2003). The findings of some studies have also shown evidence pointing towards mixed performance implications from QM practices (Dow et al. 1999). Some researchers have shown the failure of QMP in delivering the desired performance (Dooyoung et al., 1998; Pajoro \& Sohal, 2006). Dean and Bowen (1994) attribute this confusion to extension of research on quality management from manufacturing to include service industries. Failure to explore how QMP affect the performance of service industries like middle level colleges may be the reason for mixed findings. From the above review of literature, the following alternative hypothesis was derived:

$\mathbf{H}_{1}$ : Quality Management Practices have significant effects on organizational Performance

The resultant sub-hypotheses were derived as:

$\mathbf{H}_{1 \mathbf{a}}$ : Quality management practices have significant effects on financial performance

$\mathbf{H}_{\mathbf{1 b}}$ : Quality management practices have significant effects on non-financial performance

\section{Methodology}

The research aimed to establish the effect of selected quality management practices on organizational performance. The researcher adopted a positivist philosophical orientation which presumes that the social world exists objectively and externally, that knowledge is valid only if it is based on observations of this external reality and that universal or general laws exist or that theoretical models can be developed that are generalisable, explain cause and effect relationships, and which lend themselves to predicting outcomes (Cooper \& Schindler, 2008).

The study adopted a cross-sectional survey research design. In this type of research design, either the entire population or a subset thereof is selected, and from these individuals, data are collected to help answer research questions of interest (Olsen \& George, 2004). The cross-sectional study design was ideal for establishing the relationships of variables under study at a specific period of operation of firms. The cross-sectional method is ideal when information gathered represent happenings in an organization is at one point in time (Bryman, 2004). This design has also been used by Okwiri (2010) and Muchara (2012) who have studied related variables like quality management and organizational performance. 
The study entailed all ISO 9000 certified middle level colleges in Kenya. Middle level colleges refer to institutions which offer post-secondary education with the main intention of awarding a certificate or a diploma. The tertiary colleges fall under various ministries of health and Education. With the expansion of university programs, some of these colleges serve as centers for teaching degree programs.

There are a total of 185 middle level colleges in Kenya. Out of these, 93 are government run institutions. They are classified as technical training colleges, teachers' training colleges, institutes of technology and medical training colleges (Ministry of Education, 2013). There were 50 ISO certified middle level colleges as at July, 2015 (KEBS, 2015; Bureau Veritas, 2015). The study involved a census of all the ISO 9000 certified colleges.

A census survey was done due to the small number of study population which involved only the ISO 9000 Certified colleges. ISO 9000 certified Middle level colleges were chosen because they provided an opportunity to study quality management practices. Rao (1997) points out that ISO 9000 certification enables an organization to acquire quality management practices. Middle level colleges were chosen because of their role in supplying skilled labor necessary to steer the country to realize vision 2030. Majority of students who are unable to make the grade for university education get an alternative education in these institutions hence the call to uphold quality.

The study relied on both primary and secondary data. Primary data, mainly quantitative, which is concerned with quality management practices and organizational performance, was collected through questionnaires that were distributed to respondents for filling. The questionnaire was mailed by the researcher to be filled by the college principals, their deputies, registrars, dean and college management representatives who are in-charge of implementing quality management systems.

Questionnaires were organized in open ended sections intended to give general information and sections requiring respondents to rate the statements in five point likert scale according to the extent to which they agree with the statements. Use of likert scale was also embraced by Rao et al (1997), Okwiri (2010) and Machuki (2011) to study related variables. The researcher made contacts with the institutions using letters. The initial contacts were through referrals from informal contacts. Once contact was made, the researcher explained the purpose of the research and assured respondents of confidentiality and anonymity. The questionnaire was then delivered and date of collection agreed upon.

Secondary data pertaining to performance was obtained from financial records and analyses from the institutions of study. Other sources of secondary data included customer survey analyses and records on student and staff population. Evidence of embracing QMP was established by a valid certificate of ISO 9000 certification.

\section{Operationalization of Quality Management Practices and Organizational Performance}

The independent variable in the study was Quality Management Practices while the dependent variable was the organizational performance. In empirical studies that associate quality management with performance, the quality construct is normally operationalized by identifying the use of certain management practices with questionnaires and/or interviews (Powell 1995; Kaynak 2003). The quality management practices that were studied included: leadership, information analysis, strategic planning, human resource development, employee relations and customer relationships.

The dependent variable, organizational performance was operationalized through two indicators namely financial and non financial performance. Financial performance for colleges was based on surplus or deficits at the end of a financial year. Non financial performance was based on five aspects according to Kaplan and Norton (1992) and Hubbard (2009) of customer satisfaction, internal business processes, learning and growth, non market performance. Several questionnaire items were drawn which were measured on a 5 point Likert scale.

\section{Reliability and Validity of Research Instruments}

The questionnaires submitted to different colleges had the same questions to ensure consistency of results. Those submitted via the electronic mail and postal mails also had the same questions. The questionnaire was pre-tested with research experts and senior managers of colleges having similar characteristics to those of study population to ensure reliability and validity of research instrument.

Reliability refers to the extent to which an item is without bias, ensuring consistent measurement across time and across various items in the instrument (Sekaran, 2010). Therefore, reliability is an indicator of the stability and consistency with which the instrument measures the concept and helps to assess the goodness of the measure. 
Inter-item reliability was tested by determining Cronbach's alpha. The scale of inter-item reliability is between 0 and 1, with figures approaching 1 being regarded as highly reliable. There seems to be no agreement on the lower limits of Cronbach's alpha since different studies use different cut-off points. Cut off point of 0.5 has been recommended by Davis (1964) for a research population of between 24 and 50. This study adopted a Cronbach cut-off coefficient of 0.6 .

Table 1: Reliability Test

\begin{tabular}{|l|l|l|l|}
\hline Variables & Number of Items & Cronbach Alpha & Interpretation \\
\hline QMPs & 38 & 0.978 & Reliable \\
\hline Organizational Performance & 18 & 0.865 & Reliable \\
\hline
\end{tabular}

Source: Research Data, 2015

Table 1 shows Cronbach Alpha test done to determine internal consistency of collected data. The test indicated the extent to which a set of items can be treated using a single latent variable. The table shows the Cronbach Apha results of quality management practices, and organizational performance. The values range from 0.865 and 0.978 . This shows that the variables had sufficient internal consistency and therefore the items were reliable.

The validity of a measure refers to the extent to which it measures what it is intended to measure. Three different types of validity are generally considered: content validity; criterion-related validity; construct validity. Content validity depends on how well the researcher created the measurement items to cover the content domain of the variables being measured (Cooper \& Schindler, 2006). The content validity of the questionnaire was ascertained by measurement of adequate coverage of questions on strategy content, quality management practices, organizational factors and performance. The indicators that were criterion related to these concepts were associated using the Likert scale.

\section{Data Analysis}

Raw data was processed through data editing and coding. At this stage, data problems like blank responses and missing data were appropriately dealt with through case wise approach when missing data was of a variable of interest (Hahn \& Doh, 2006). Data was entered into the SPSS system in readiness for analysis. IBM SPSS version 21 was used to analyze the data.

The study used one sample t-test for descriptive statistics. The major statistical measure of the relationship is the correlation coefficient. In order to know the most contributory of this relationship between the variables, the multiple regressions was be conducted since the study entailed more than two variables. Sekaran (2003) described the multiple regressions as a statistical technique to predict the variance in a single dependent variable caused by the effect of more than one independent variable. In other words, correlation indicates the existence of the relationship between the variables while the multiple regressions specify the most crucial variables for this relationship. A significance level of $95 \%$ ( $\mathrm{p}$ value of 0.05 ) was used in the study. Hypothesis testing was done to ascertain the level of significance between the variables of study. Simple regression was used to test the subhypotheses.

The general regression model of the study variables are expressed as:

Performance $=\mathrm{f}(\mathrm{QMP}+$ Error term $)$

$\mathrm{Y}=\beta_{0}+\beta_{1} \mathrm{X}_{1}+\varepsilon$

Where:

$\mathrm{Y}=$ aggregate mean score of organizational Performance

$\beta_{0}=\mathrm{y}$ intercept/ constant

$\beta_{1}=$ regression coefficient

$\mathrm{X}_{1}=$ Quality Management Practices

$\varepsilon=$ Error term 
Table 2: Analytical Models for Corresponding Objectives and Hypotheses

\begin{tabular}{|c|c|c|c|}
\hline Objective & Hypotheses & Analytical Model & Test Statistics \\
\hline $\begin{array}{l}\text { To establish the } \\
\text { influence of } \\
\text { QMPs } \\
\text { organizational } \\
\text { performance }\end{array}$ & $\begin{array}{ll}\text { H}_{1}: \text { QMPs } & \text { have } \\
\text { significant effects on } \\
\text { organizational } \\
\text { performance }\end{array}$ & $\begin{array}{l}\text { Multiple regression analysis } \\
\mathrm{Y}_{1}=\mathrm{f}(\mathrm{QMPs}) \\
\mathrm{Y}=\beta_{0}+\beta_{1} \mathrm{X}_{1}+\varepsilon \\
\text { Where } \\
\mathrm{Y}=\text { Organizational performance } \\
\beta_{0}=\mathrm{Y} \text { Intercept/Constant } \\
\beta_{1} \quad=\quad \text { Regression Coefficients, } \\
\mathrm{X}_{1}=\mathrm{QMPs} \\
\varepsilon=\text { error term }\end{array}$ & $\begin{array}{l}\text { Pearson's correlation, } \mathrm{R}, \\
\mathrm{R}^{2}, \text { F-Ratio, P-Value }\end{array}$ \\
\hline
\end{tabular}

Table 2 shows a summary of analytical models for corresponding objectives and hypotheses. Interpretations for the analytical models are also shown

\section{Findings}

Data was obtained from 43 out of the target population of 50. Of the returned questionnaires, one questionnaire was rejected since it had incomplete information. The questionnaire which were useful were 42 . The response rate was therefore 84 percent which compares well with other studies like Kinuu (2014) who had 75 percent response rate.

\section{Organizational Demographics}

Organizational demographics used in this study focused on the population of employees, both teaching and non teaching, the number of students, the number of courses offered in an institution, the types of certificates awarded, IS0 9000 certification status, years passed since certification and reasons for embracing certification.

The size of an organization was measured by the population of staff and the students and the number of courses offered. The size of an organization is an indicator of modes of strategy application and the ease of implementation of strategies. Pilot study showed that most colleges had teaching staff and non-teaching staff populations in the range of 50 and 500. Most colleges had student population between 100 and 2000 with very few colleges having student populations above this range.

Table 3: Teaching Staff Population

\begin{tabular}{|c|c|c|c|}
\hline $\begin{array}{l}\text { Population of Teaching } \\
\text { Staff }\end{array}$ & Frequency & Percentage & Cumulative Percentage \\
\hline $50-149$ & 30 & 71.4 & 71.4 \\
\hline $150-249$ & 8 & 19.0 & 90.5 \\
\hline $250-349$ & 2 & 4.8 & 95.2 \\
\hline 500 and above & 2 & 4.8 & 100.0 \\
\hline Total & 42 & 100.0 & \\
\hline
\end{tabular}

Source: Research Data, 2015

Table 3 shows the population of teaching staff in the colleges studied. The table shows that majority of colleges had teaching staff population between 50 and 149 with 71.4 Percent while two organizations had staff populations in the range of 250 to 349 and 500 and above.

The population of non teaching staff was also sort in the study. The non teaching staffs form the bulk of staff that have supportive role in ensuring success of strategies. They are not involved directly in teaching but ensure that learning activities are smoothly performed. The table 1.4 below shows the descriptive statistics of non teaching staff as per the population frequency. 
Table 4: Population of Non-teaching Staff

\begin{tabular}{|l|l|l|l|l|}
\hline $\begin{array}{l}\text { Population of } \\
\text { Non-Teaching Staff }\end{array}$ & Frequency & Percentage & $\begin{array}{l}\text { Cumulative } \\
\text { Percentage }\end{array}$ \\
\hline & & & & 92.7 \\
\hline $\mathbf{5 0 - 1 4 9}$ & 38 & 90.5 & 95.1 \\
\hline 500 and above & 2 & 2.4 & 100.0 \\
\hline
\end{tabular}

Source: Research Data, 2015

From Table 4, the population range which had the highest number was between 50 to 149 with a percentage frequency of $90.5 \%$, followed by 500 and above with a percentage of $4.8 \%$ and lastly 150 to 249 with a percentage of $2.4 \%$. One questionnaire had no response about non-teaching staff.

The researchers also analyzed the data on the population of students in the colleges under study. Table 1.5 below presents the student population ranges. The ranges are from 100 to 499, 500 to 999, 1000 to 1499,1500 to 1999 and 2000 and above. The statistics are presented in Table 5.

Table 5: Student Population

\begin{tabular}{|l|l|l|l|}
\hline Student Population & Frequency & Percentage & Cumulative Percentage \\
\hline $100-499$ & 6 & 14.3 & 14.3 \\
\hline $500-999$ & 16 & 38.1 & 52.4 \\
\hline $1000-1499$ & 6 & 14.3 & 66.7 \\
\hline $1500-1999$ & 5 & 11.9 & 78.6 \\
\hline 2000 and above & 9 & 21.4 & 100.0 \\
\hline Total & 42 & 100.0 & \\
\hline
\end{tabular}

Source: Research Data, 2015

Table 5 shows the population of students. Colleges with the highest number of students fell in the range between 500 and 999 which accounted for $38.1 \%$, followed by the range between 2000 and above which had 21.4 percent. The range between 1500 and 1999 had the lowest student population. Table 6 presents the size of colleges according to the number of specialization. The specializations were aggregated in the ranges between 10-19, 2029, 30-39 and 40 and above.

Table 6: Number of Areas of Specialization

\begin{tabular}{|c|c|c|c|c|}
\hline & Areas of Specialization & Frequency & Percentage & Cumulative Percentage \\
\hline & $10-19$ & 23 & 54.8 & 57.5 \\
\hline & $20-29$ & 12 & 28.6 & 87.5 \\
\hline & $30-39$ & 2 & 4.8 & 92.5 \\
\hline & 40 and above & 3 & 7.1 & 100.0 \\
\hline Total & & 42 & 100.0 & \\
\hline
\end{tabular}

Source: Research Data, 2015

Table 6 shows that most colleges offered specializations in the range of 10-19. This was followed by a range of between 20 to 29. The lowest range was between 30 to 39 which constituted $4.8 \%$. The small number of courses indicates that most colleges were small in size and hence offered limited chances in specialization. Two institutions failed to fill this part of the questionnaire. Table 7 presents the characteristics of colleges with regard to the types of certificates awarded. The levels of certificates awarded range from certificate for craft courses, diploma and degree. 
Table 7: Types of Certificates Awarded

\begin{tabular}{|l|l|l|l|}
\hline Certificates awarded & Frequency & Percentage & Cumulative Percentage \\
\hline Certificate & 1 & 2.4 & 2.4 \\
\hline Diploma & 2 & 4.8 & 7.1 \\
\hline Both certificate and diploma & 37 & 88.1 & 95.2 \\
\hline Degree & 2 & 4.8 & 100.0 \\
\hline Total & 42 & 100.0 & \\
\hline
\end{tabular}

Source: Research Data, 2015

Table 7 shows the types of certificates awarded. Most colleges awarded certificate and diplomas, constituting $88.1 \%$ of the number of colleges. Few colleges $(4.8 \%)$ reported offering degree courses as well. The two colleges explained that these degrees were offered with assistance of main universities. Since the colleges in this study are middle level colleges, it is expected that most of them will offer qualifications in the range of certificates and diplomas as depicted by this analysis. Table 8 shows ISO 9000 Certification status of colleges.

Table 8: ISO 9000 Certification Status

\begin{tabular}{|l|l|l|l|}
\hline ISO 9000 Certification Status & Frequency & Percent & Cumulative Percent \\
\hline Certified & 42 & 100.0 & 100.0 \\
\hline
\end{tabular}

Source: Research data, 2015

Table 8 shows all colleges were ISO 9000 certified. Certification status is an indicator of entrenchment of quality management practices. It can therefore be concluded that all colleges at the time of study practiced quality management as per the specifications of ISO 9000. To determine how well quality management practices were entrenched, it was necessary to determine for how long these colleges had been ISO 9000 certified. Table 9 presents the period colleges had been certified.

Table 9: Number of Years since Certification

\begin{tabular}{|ll|l|l|l|}
\hline Years taken since certification & Frequency & Percent & Cumulative Percent \\
\hline \multirow{3}{*}{ Valid } & Three years or less & 19 & 45.2 & 45.2 \\
\cline { 2 - 5 } & More than three years & 23 & 54.8 & 100.0 \\
\cline { 2 - 5 } & Total & 42 & 100.0 & \\
\hline
\end{tabular}

Source: Research Data, 2015

Table 9 focused on determining how long colleges had taken since they got certified. It shows that 23 colleges, constituting $54.8 \%$ had been certified for a period beyond three years. 19 colleges reported having been certified for a shorter period of three years and below. This constituted 45.2 percent of all colleges.

\section{Tests of Normality}

Parametric tests assume that data is normally distributed hence the mean is used as a measure of central tendency. Other measures that are done with the assumption of normal distribution of data include t-test, regression and correlation (Zikmund, 2010). For various reasons, a data set may be skewed. This necessitates the test for normality since when normality tests do not hold, accurate and reliable conclusions cannot be drawn (Ghasemi \& Zahediasl, 2012).

Shapiro Wilk's test was done to determine normality in this data set. If Shapiro Wilk's test is less than 0.5, there is significant deviation of the data from the normal distribution. The data in this study were subjected to Shapiro Wilk test and the results are displayed in Table 10. From the table, all the values are above 0.5 indicating normal distribution.

Table 10: Shapiro Wilk's Test

\begin{tabular}{|l|l|l|l|}
\hline \multirow{2}{*}{ Items } & Shapiro - Wilk & Sig. \\
\cline { 2 - 4 } & Statistics & df & Sic \\
\hline Strategy contents & 0.846 & 42 & 0.012 \\
\hline Quality Management Practices & 0.927 & 42 & 0.074 \\
\hline Organizational Factors & 0.922 & 42 & 0.058 \\
\hline
\end{tabular}

Source: Research data, 2015 


\section{Descriptive Statistics of QMPs}

Table 11 gives a summary of QMPs. The respondents were asked to give a score between 1 and 5 for the quality management practices (QMPs). The scores were $1=$ Not at all, $2=$ Small extent, $3=$ moderate extent, $4=$ large extent, 5=very large extent. A series of questions were asked that captured components of QMPs. From the table, structure and systems had very high mean scores indicating that respondents agreed to a large extent that statements about supplier relationship applied to their organizations. The lowest mean was recorded on information analysis (3.7619). The highest variability was on information analysis which had a standard deviation of 0.75900 .

Table 11: Descriptive Statistics of QMPs

\begin{tabular}{|c|c|c|c|c|c|c|}
\hline Constructs & $\mathrm{N}$ & Mean & Std. Deviation & $\mathrm{t}$ & $\begin{array}{l}\text { Sig. } \\
\text { tailed) }\end{array}$ & $\begin{array}{l}\text { Coefficient } \\
\text { of variation } \\
\%\end{array}$ \\
\hline Top Management Support & 42 & 3.9940 & .64508 & 40.126 & .000 & 16.2 \\
\hline Customer Relationship & 42 & 3.9694 & .54149 & 47.507 & .000 & 13.7 \\
\hline Supplier Relationship & 42 & 4.2262 & .66445 & 41.220 & .000 & 15.7 \\
\hline Employee Involvement & 42 & 4.0595 & .72585 & 36.245 & .000 & 17.9 \\
\hline Human Resource Development & 42 & 3.8929 & .74519 & 33.855 & .000 & 19.1 \\
\hline Quality Assurance & 42 & 3.9476 & .61693 & 41.469 & .000 & 15.6 \\
\hline Strategic Quality Planning & 42 & 3.8929 & .74519 & 33.855 & .000 & 19.1 \\
\hline Information Analysis & 42 & 3.7619 & .75900 & 32.121 & .000 & 20.1 \\
\hline
\end{tabular}

Source: Research Data, 2015

\section{Descriptive Statistics of Organizational Performance}

Table 12 presents the descriptive statistics for organizational performance. The highest coefficient of variation was on financial performance, meaning that most responses were varied about financial performance while the lowest coefficient of variation was on the aspect of learning and growth. The highest mean was on learning and growth (19.619) while the lowest mean was on environmental and social aspect performance. Financial performance had the highest standard deviation while social and environmental performance had the lowest standard deviation.

Table 12: Descriptive Statistics for Organizational Performance

\begin{tabular}{|l|l|l|l|l|l|l|}
\hline Constructs & $\mathrm{N}$ & Mean & Std. Deviation & $\mathrm{t}$ & $\begin{array}{l}\text { Coefficient } \\
\text { variation } \%\end{array}$ & Sig. (2-tailed) \\
\hline Customer Perspective & 42 & 12.1667 & 1.70961 & 46.121 & 14.1 & .000 \\
Financial Performance & 42 & 13.7143 & 5.30203 & 16.763 & 38.7 & .000 \\
Internal Business Process & 42 & 11.3810 & 1.51339 & 48.736 & 13.3 & .000 \\
Learning Growth & 42 & 19.6190 & 2.34731 & 54.167 & 12 & .000 \\
Social and Environmental \\
Performance
\end{tabular}

Source: Research Data, 2015

\section{Results of Test of Hypothesis}

The objective of the study was to determine the effect of Quality Management Practices on organizational performance. To test the hypothesis, the correlation effect of QMPs and organizational performance was determined. The significance effect of QMPs on organizational performance was tested. The correlations were used to measure the correlation strengths of variables of study. Significance effects test the coefficients, $t$-value, and $\mathrm{p}$-values. The combined effects of QMPs on organizational performance explains the correlation coefficient $(\mathrm{R})$, the coefficient of determination $\left(\mathrm{R}^{2}\right)$, level of significance and the overall statistical significance (F-ratio). 
Table 13: QMPs and Organizational performance

Table 13a: Model Summary ${ }^{\mathrm{b}}$

\begin{tabular}{|l|l|l|l|l|l|}
\hline Model & $\mathrm{R}$ & R Square & $\begin{array}{l}\text { Adjusted } \\
\text { Square }\end{array}$ & $\begin{array}{l}\text { Rtd. Error of the } \\
\text { Estimate }\end{array}$ & Durbin-Watson \\
\hline 1 & $.717^{\mathrm{a}}$ & .514 & .396 & 7.24530 & 2.694 \\
\hline
\end{tabular}

a. Predictors: (Constant), Human Resource Dev, Strat quality planning, Information Analysis, Supplier Relations, Top management support, Customer Relations, Employee Involvement, Quality Assurance

b. Dependent Variable: Organizational Performance

Table 13b: ANOVA ${ }^{\mathrm{a}}$

\begin{tabular}{|c|c|c|c|c|c|c|}
\hline \multicolumn{2}{|c|}{ Model } & Sum of Squares & df & Mean Square & F & Sig. \\
\hline \multirow{4}{*}{1} & Regression & 1832.091 & 8 & 229.011 & 4.363 & $.001^{\mathrm{b}}$ \\
& Residual & 1732.313 & 33 & 52.494 & & \\
& Total & 3564.405 & 41 & & & \\
\hline
\end{tabular}

a. Dependent Variable: Organizational Performance

b. Predictors: (Constant), Human Resource Dev, Strategic quality planning, Information Analysis, Supplier Relations, Top management support, Customer Relations, Employee Involvement, Quality Assurance

Table 13c: Coefficients ${ }^{\mathrm{a}}$

\begin{tabular}{|c|c|c|c|c|c|c|}
\hline \multirow[t]{2}{*}{ Mod } & & \multicolumn{2}{|c|}{$\begin{array}{l}\text { Unstandardized } \\
\text { Coefficients }\end{array}$} & \multirow{2}{*}{\begin{tabular}{|l} 
Standardized \\
Coefficients \\
Beta
\end{tabular}} & \multirow[t]{2}{*}{$\mathrm{t}$} & \multirow[t]{2}{*}{ Sig. } \\
\hline & & $\mathrm{B}$ & Std. Error & & & \\
\hline \multirow{9}{*}{1} & (Constant) & 25.105 & 8.887 & & 2.825 & .008 \\
\hline & Top management support & -.897 & 1.151 & -.248 & -.780 & .441 \\
\hline & Customer Relations & .539 & .727 & .219 & .741 & .464 \\
\hline & Supplier Relations & .588 & 1.675 & .084 & .351 & .728 \\
\hline & Employee Involvement & .224 & .624 & .112 & .359 & .722 \\
\hline & Information Analysis & .239 & 1.450 & .038 & .164 & .870 \\
\hline & Quality Assurance & .240 & .590 & .159 & .408 & .686 \\
\hline & Strategic Quality Planning & -.433 & 1.501 & -.067 & -.288 & .775 \\
\hline & Human Resource Dev & 2.645 & 1.503 & .431 & 1.760 & .088 \\
\hline
\end{tabular}

a. Dependent Variable: Organizational Performance

Source: Research Data, 2015

Table 13a illustrates the effect of QMPs on organizational performance. The table provides the $\mathrm{R}$ and $\mathrm{R}^{2}$ values. The $\mathrm{R}$ value is .717, which represents the simple correlation and therefore, indicates a strong degree of correlation. The $\mathrm{R}^{2}$ indicates how much of the dependent variable, organizational performance can be explained by the independent variable, QMPs. In this case, $51.4 \%\left(\mathrm{R}^{2}=.514\right)$ can be explained.

The ANOVA Table (13b) indicates that the regression model predicts the outcome variable significantly well. The table shows that there was statistically significant difference between the means of QMPs and organizational performance $(F(1)=4.363, p=0.001)$. Since the $P$-value is less than the significance level $(0.05)$, we reject the null hypothesis. Thus there is significance difference between the means of QMPs and organizational performance.

The Coefficients Table (13c) shows the significance effects of QMPs on organizational performance. The table indicates that there were no significant effects of individual QMPs on performance since the $p$-value was greater than 0.05 though the sum of QMPs had significant effect on performance. 
14a: Model Summary ${ }^{\mathrm{b}}$

Table 14: Effect of QMPs on Non Financial Performance

\begin{tabular}{|c|c|c|c|c|c|}
\hline Model & $\mathrm{R}$ & $\mathrm{R}$ Square & Adjusted R Square & $\begin{array}{c}\text { Std. Error of the } \\
\text { Estimate }\end{array}$ & Durbin-Watson \\
\hline 1 & $.854^{\mathrm{a}}$ & .729 & .663 & 3.21563 & 2.115 \\
\hline
\end{tabular}

a. Predictors: (Constant), Human Resource Dev, Strategic quality planning, Information Analysis, Supplier Relations, Top management support, Customer Relations, Employee Involvement, Quality Assurance

b. Dependent Variable: Non Financial Performance

14b: ANOVA $^{\mathrm{a}}$

\begin{tabular}{|ll|l|l|l|l|l|}
\hline Model & & Sum of Squares & df & Mean Square & F & Sig. \\
\hline \multirow{4}{*}{1} & Regression & 916.891 & 8 & 114.611 & 11.084 & $.000^{\mathrm{b}}$ \\
& Residual & 341.228 & 33 & 10.340 & & \\
& Total & 1258.119 & 41 & & & \\
\hline
\end{tabular}

a. Dependent Variable: Non Financial Performance

b. Predictors: (Constant), Human Resource Dev, Strategic quality planning, Information Analysis, Supplier Relations, Top management support, Customer Relations, Employee Involvement, Quality Assurance

14c: Coefficients ${ }^{\mathrm{a}}$

\begin{tabular}{|c|c|c|c|c|c|c|}
\hline \multirow[t]{2}{*}{ Mod } & & \multicolumn{2}{|c|}{ Unstandardized Coefficients } & \multirow{2}{*}{$\begin{array}{l}\text { Standardized } \\
\text { Coefficients } \\
\text { Beta }\end{array}$} & \multirow[t]{2}{*}{$\mathrm{t}$} & \multirow[t]{2}{*}{ Sig. } \\
\hline & & $\mathrm{B}$ & Std. Error & & & \\
\hline \multirow{9}{*}{1} & (Constant) & 19.779 & 3.944 & & 5.015 & .000 \\
\hline & Top management support & -.111 & .511 & -.052 & -.218 & 829 \\
\hline & Customer Relations & .545 & .323 & .373 & 1.689 & 101 \\
\hline & Supplier Relations & .822 & .743 & 197 & 1.106 & .277 \\
\hline & Employee Involvement & .172 & .277 & 144 & .620 & 539 \\
\hline & Information Analysis & -.008 & .644 & -.002 & -.013 & 990 \\
\hline & Quality Assurance & .060 & .262 & .067 & .228 & 821 \\
\hline & Stratquality planning & -.657 & .666 & -.172 & -.986 & .331 \\
\hline & Human Resource Dev & 1.207 & .667 & .331 & 1.810 & .079 \\
\hline
\end{tabular}

Dependent Variable: Non Financial Performance

Source: Research Data, 2015

Table 14a illustrates the effect of QMPs on non-financial performance. The table provides the $R$ and $R^{2}$ values. The $R$ value is .854, which represents the simple correlation and therefore, indicates a strong degree of correlation. The $\mathrm{R}^{2}$ indicates how much of the dependent variable, non financial performance can be explained by the independent variable, QMPs. In this case, $72.9 \%\left(\mathrm{R}^{2}=.729\right)$ can be explained.

The ANOVA Table (14b) indicates that the regression model predicts the outcome variable significantly well. The table shows that there was statistically significant difference between the means of QMPs and non-financial performance $(\mathrm{F}(8)=11.084, \mathrm{p}=0.000)$. Since the $\mathrm{P}$-value is less than the significance level $(0.05)$, we reject the null hypothesis. Thus there was significance difference between the means of QMPs and non-financial performance.

The Coefficients Table (14c) shows the significance effects of QMPs on non-financial performance. The table indicates that there were no significant effects of individual QMPs on performance since the $p$-values were greater than 0.05 except for the constant. The sum of QMPs had significant effect on non-financial performance. The Durbin Watson statistic of 2.11 shows there was no auto-correlation. 


\section{Table 15: Effect of QMPs on Financial Performance}

15a: Model Summary ${ }^{\mathrm{b}}$

\begin{tabular}{|l|l|l|l|l|l|}
\hline Model & $\mathrm{R}$ & R Square & Adjusted R Square & $\begin{array}{l}\text { Std. Error of the } \\
\text { Estimate }\end{array}$ & Durbin-Watson \\
\hline 1 & $.424^{\mathrm{a}}$ & .180 & -.019 & 5.35209 & 2.749 \\
\hline
\end{tabular}

a. Predictors: (Constant), Human Resource Dev, Strategic quality planning, Information Analysis, Supplier Relations, Top management support, Customer Relations, Employee Involvement, Quality Assurance b. Dependent Variable: Financial Performance

15b: ANOVA ${ }^{\mathrm{a}}$

\begin{tabular}{|c|c|c|c|c|c|c|}
\hline \multicolumn{2}{|l|}{ Model } & Sum of Squares & $\mathrm{df}$ & Mean Square & $\mathrm{F}$ & Sig. \\
\hline \multirow{3}{*}{1} & Regression & 207.291 & 8 & 25.911 & .905 & $.524^{\mathrm{b}}$ \\
\hline & Residual & 945.281 & 33 & 28.645 & & \\
\hline & Total & 1152.571 & 41 & & & \\
\hline
\end{tabular}

a. Dependent Variable: Financial Performance

b. Predictors: (Constant), Human Resource Dev, Strategic quality planning, Information Analysis, Supplier Relations, Top management support, Customer Relations, Employee Involvement, Quality Assurance

15c: Coefficients ${ }^{\mathrm{a}}$

\begin{tabular}{|c|c|c|c|c|c|c|}
\hline \multirow{2}{*}{\multicolumn{2}{|c|}{ Model }} & \multicolumn{2}{|c|}{ Unstandardized Coefficients } & \multirow{2}{*}{\begin{tabular}{|l}
$\begin{array}{l}\text { Standardized } \\
\text { Coefficients }\end{array}$ \\
Beta
\end{tabular}} & \multirow[t]{2}{*}{$t$} & \multirow[t]{2}{*}{ Sig. } \\
\hline & & $\mathrm{B}$ & Std. Error & & & \\
\hline \multirow{9}{*}{1} & (Constant) & 5.326 & 6.565 & & .811 & .423 \\
\hline & Top management support & -.786 & .850 & -.383 & -.925 & .362 \\
\hline & Customer Relations & -.006 & .537 & -.005 & -.012 & .991 \\
\hline & Supplier Relations & -.234 & 1.237 & -.059 & -.189 & .851 \\
\hline & Employee Involvement & .052 & .461 & .046 & .114 & .910 \\
\hline & Information Analysis & 247 & 1.071 & .069 & .230 & .819 \\
\hline & Quality Assurance & 181 & .436 & .210 & .415 & .681 \\
\hline & Stratquality planning & .224 & 1.109 & .061 & .202 & .841 \\
\hline & HumanResourceDev & 1.437 & 1.110 & .412 & 1.295 & .204 \\
\hline
\end{tabular}

a. Dependent Variable: Financial Performance

Source: Research Data, 2015

Table 15a illustrates the effect of QMPs on financial performance. The table provides the $\mathrm{R}$ and $\mathrm{R}^{2}$ values. The $\mathrm{R}$ value is .424 , which represents the simple correlation and therefore, indicates a moderate degree of correlation. The $\mathrm{R}^{2}$ indicates how much of the dependent variable, financial performance can be explained by the independent variable, QMPs. In this case, $18 \%\left(\mathrm{R}^{2}=.180\right)$ can be explained.

The ANOVA Table (15b) indicates that the regression model predicts the outcome variable significantly well. The table shows that there was no statistically significant difference between the means of QMPs and financial performance $(F(8)=.905, p=0.524)$. Since the $\mathrm{P}$-value is greater than the significance level $(0.05)$, we do not reject the null hypothesis. Thus there was no significance difference between the means of QMPs and financial performance.

The Coefficients Table (15c) shows the significance effects of QMPs on financial performance. The table indicates that there were no significant effects of individual QMPs on performance since the p-values were greater than 0.05. The sum of QMPs had significant effect on non-financial performance. Durbin Watson statistic of 2.74 shows there was no autocorrelation.

\section{Discussion of Findings}

The results of data analysis show that quality management practices (QMPs) have significant effect on organizational performance of ISO 9000 Certified middle level colleges. 
The results show that collectively, quality management practices have influence on performance while individually, they don't contribute to performance. The findings corroborate those of Pajoro and Sohal (2006) and those of Powell (1995) which shows that quality management practices influence organizational performance. Okwiri (2010) and Muchara (2012) while studying governmental agencies and horticultural firms respectively came to the findings that QMPs are essential for realizing operational performance objectives. The findings allude to the fact that the practices should be applied as a whole and not as single entities.

The results show that QMPs have significant effects on non financial performance but do not have significant effects on financial performance. Pajoro and Sohal (2004) argue that implementing QMP could lead either to a firm being innovative hence a differentiator or through customer focus, innovation could be impaired. Hall (1983) posits that implementing QMP could increase running costs of a firm. This position is contested by Ferdows and De Meyer (1990) who argue that QMP leads to continuous improvement and cost reduction. The high initial costs of implementing QMPs could be the reason for poor financial performance since more money is used to implement the QMPs hence lowering financial benefits.

The findings of this research help to answer the questions; what is the value of implementing QMPs? Is QMPs a preserve for manufacturing firm? The results of the research show that there are benefits that result from implementing QMPs. These include customer satisfaction; it stimulates innovation and creativity, enhances social responsibility and causes operational efficiency. The findings however find no relationship between embracing QMPs and financial performance. It is noted that QMPs are as applicable to service industries like educational sector as it is in manufacturing firms. The results of this research could be generalizable in the context of ISO certified middle level colleges.

\section{Implications of the Study}

The study has anchored the use of SBSC in quality management research. Most studies have used financial performance as traditional measure of performance. While the use of financial measure of performance remains valid, it fails to provide a holistic view of an organizational performance since non-financial and less tangible aspects of performance such as customer perspective, learning and growth and environmental performance are not considered (Kaplan and Norton, 1992). The inclusion of stakeholder theory in this study has enabled the use of contemporary frameworks of performance like the sustainable balanced score card. The study has implications for neo-institutional theory and resource based view. The study shows that organizations are not passive implementers of environmental cues like QMPs and that indeed; these cues can be used to enhance organizational performance. Even though embracing ISO 9000 certification may be a performance requirement, aligning organizational factors with these practices can culminate into better performance.

Practitioners and managers in the field of education can draw upon the findings in this study on the importance of embracing QMPs to help realize organizational strategies. The findings of this study therefore lend itself to managerial scrutiny on the adoption of quality management practices and aligning strategies to achieve performance goals. The principal focus of this study was to explain statistical relationships. The study has examined the processes which cause these relationships as suggested by Lenz (1981). Methodological choices have gone beyond the choice of statistical models to testing the interactions among various variables in this study.

Findings of this study provide a basis for policy makers to decide on ISO 9000 certification benefits and adopting sustainable balance score card in measuring organizational performance. The findings from this study expose the inadequacy of financial performance as indicators of organizational performance.

\section{Limitations of the Study and Suggestions for Further Research}

Given that most middle level colleges have adopted QMPs in a period of three years and below, the use of cross sectional study may not provide a complete picture of how QMPs affect performance in the long term. Perhaps, the use of longitudinal study approach may provide a different angle on the interplay of these variables on performance considering that like any practice, time has a factor of cementing QMPs in organizations. Replication plays an important role in the external validation of cause and effect relationship. Hubbard and Vetter (1996) state that replication research aids in ensuring the integrity of a discipline's empirical results and in contributing to knowledge by guarding against type one error (errors of rejection of the null hypothesis). In line with this, there is need to replicate this study after a period of time to establish if the findings stand the test of time. 


\section{References}

Boyne ,A., George A., Stephen Martin. , \& Richard, M .W. (2004). Explicit Reforms, Implicit Theories and Public Service Improvement. Public Management Review 6 (2): 189 - 210

Cooper, R.D., \& Schindler,S.P. (2008). Business Research Methods. $8^{\text {th }}$ Ed. Boston; Irwin McGraw-Hill.

Davis, F.B. (1964). Educational Measurements and Their Interpretation. Belmont, C.A: Wadworth.

Dean, J.W., \& Bowen, D.E. (1994). Management theory and total quality: improving research and practice through theory development. Academy of Management Review 19 (3), 393-418.

DiMaggio, P.J.,\& Powell, W.W. (1991). The new Institutionalism and Organization Analysis. University of Chicago Press. Chicago.

Dooyoung, S., Kalinowski, J.G., \& El-Enein, G. (1998). Critical implementation issues in total quality management. SAM Advanced Management Journal 63 (1), 10-14.

Douglas, T. J., \& Judge W. Q. (2001). Total Quality Management Implementation and Competitive Advantage: The Role of Structural Control and Exploration. The Academy of Management Journal, Vol. 44(1), 158169.

Ferdows, K., \& DeMeyer, A. (1991). Lasting Improvements in Manufacturing Performance: In Search of a New Theory. Journal of Operations Management 9 (April): 168-184

Dow, D., Samson, D., \& Ford, S. (1999). Exploring the myth: do all quality management practices contribute to superior quality performance? Production and Operations Management 8, 1-27.

Ghasemi, A., \& Zahediasl, S. (2012). Normality Tests for Statistical analysis; a guide for non-staticians. International Journal for Endocrinology and metabolism, 10(2), 486-489.

Grant, R.M (1991). The Resource -Based Theory of Competitive Advantage: Implications for Strategy Formulation. California Management Review, 33(Spring), 114-135.

Ho, D.C.K., Duffy, V.G., \& Shih, H.M., (2001). Total quality management: an empirical test for mediation effect. International Journal of Management 17, 842-873.

Hubbard, G. (2009). Measuring Organization Performance; Beyond Tripple Bottom Line. Business Strategy and Environment. 19, 177-191.

Hubbard, R., \& Vetter, D.E. (1996). An Empirical Comparison of Published Replication Research in Accounting, Economics, Finance, Management and Marketing. Journal of Business Research 35 (2), 153-164.

Kaplan, R, S., \& Norton, D.P. (1992). The Balanced Scorecard-Measures that drive Performance. Harvard Business Review 70 (1) 71-79.

Kaynak, H. (2003). The relationship between total quality management practices and their effects on firm performance. Journal of Operations Management 21, 405-435

Lenz, R. T. (1981). Determinants of organizational Performance: An interdisciplinary review. Strategic Management Journal, 2(2), 131-154.

Machuki, V.N. (2011). External environment-strategy coalignment, firm- level institutions and performance of publicly quoted companies in Kenya. Unpublished Ph.D thesis, University of Nairobi.

Muchara, M. (2012). Total quality, operational effectiveness and competitive advantage in horticultural industry in Kenya. Unpublished Ph.D thesis, University of Nairobi.

Okwiri, O.A. (2010). The relationship between ISO 9001 certification status and operational performance of Government agencies. Unpublished Ph.D thesis, University of Nairobi.

Oslen, C. \& George, M. M. M. (2004). Cross-Sectional Study Design and Data Analysis. The Young Epidemiology Scholars Program, Walden University- Chicago, Illinois ownership structure. Journal of Financial Economics: 305-360.

Pajogo, D. I. \& Sohal, S.A. (2006). Approaches to Adopting Quality in SMEs and the Impact on Quality Management Practices and Performance. Total Quality Management, Vol. 17,(5), 555-566.

Pearce, J.A., \& Robinson, R. B. (2005). Strategic Management: Formulation, Implementation and Control. Irwin: McGraw-Hill.

Phillips, L., D. Chang, \& Buzzell, R. (1983). Product Quality, Cost Position and Business Performance: A Test of Some Key Hypotheses. Journal of Marketing, 47, Spring, 26-43.

Porter, M. E. (1980). Competitive strategy. New York: Free Press. 
Powell, T. (1995). Total quality management as competitive advantage: A review and empirical study. Strategic Management Journal, 16: 15-37.

Rao, S. S., L. E. Solis, \& Raghu-Nathan. (1999). A Framework for International Quality Management Research: Development and Validation of a Measurement. Total Quality Management, 10(7), 1047-1075.

Saraph, J.V., Benson, P.G. \& Schroeder, R.G. (1989) An instrument for measuring the critical factors of quality management, Decision Sciences, 20, 810-829.

Saunders, M., Lewis, P., \& Thornhill, A. (2007). Research Methods for Business Students. (4 ${ }^{\text {th }}$ ed.). London:

Sekaran, U. (2003). Research Methods for Business: A Skill Building Approach. (4 ${ }^{\text {th }}$ ed.). New York: John Wiley and Sons.

Zikmund, W, G., babin, B.J., Carr, J.C., \& Griffin, M. (2010). Business Research Methods. $8^{\text {th }}$ Ed. South Western, Cage Learning. 